\title{
Editorial to the special issue
}

\author{
Financialisation, distribution and crises
}

\section{Eckhard Hein}

Berlin School of Economics and Law, Germany

The global financial crisis and the ensuing Great Recession, as well as the following euro crisis, remain of interest and concern, not only because of the severe difficulties in recovering from these crises in major parts of the world economy, and in the euro area in particular. As is well known, these difficulties have triggered a renewed debate on 'secular stagnation', which we covered in Volume 13, Issue 2 (2016) of EJEEP, the Papers and Proceedings issue of the 19th conference of the Research Network Macroeconomics and Macroeconomic Policies (FMM) on 'The spectre of stagnation? Europe in the world economy'. Previous versions of the papers contained in the current special issue on 'Financialisation, distribution and crises' were presented and discussed at the same conference in October 2015 in Berlin. We have invited the authors to submit their papers to $E J E E P$, because they shed some new light on the causes and the consequences of the financial and economic crises, focusing on interesting examples and applying different types of methods and models.

The first two papers are on the case of Iceland. Björn Rúnar Guðmundsson in 'Financialisation and financial crisis in Iceland' provides a detailed case study on the long-run process of financialisation in that country. He focuses on the effects of rising financial activity on income distribution as well as on household and corporate behaviour, which has then led to the crisis, and he discusses the changes in the course of the crisis, a shift from a debt-led towards an export-led growth type of development in Iceland. In 'Could the Icelandic banking collapse of 2008 have been prevented? The role of economists prior to the crisis', John S.L. McCombie and Marta R.M. Spreafico touch upon professional economic reports on the Icelandic financial system before the crisis and deal with the question of why there have been completely opposing views on the (in)stability of the system. They argue that these are related to different methodologies and assumptions regarding the effectiveness of financial regulation being made in these reports.

The third paper is on the Netherlands, and Huub Meijers, Joan Muysken and Olaf Sleijpen present 'Firms' excess savings and the Dutch current-account surplus: a stockflow consistent approach'. Firms' positive financial balances - that is, retained earnings exceeding investment - are explained by the tendencies towards financialisation and the related preference of firms to invest in financial assets abroad instead of expanding the real capital stock at home. This establishes a close link between firms' excess saving and the current-account surplus, on the one hand, and a close relationship between net household saving and government budget deficits, on the other.

The final paper in this special issue, by Markus P.A. Schneider, Stephen Kinsella and Antoine Godin on 'Changes in the profile of inequality across Europe since 2005: austerity and redistribution', focuses on the distributional effects of austerity policies after the crisis. The authors show that austerity has increased inequality in euro area countries, but not in those European countries that have kept their own currencies and were able to deflate without cutting wages at the bottom that sharply. 